\title{
Effect of Storage on Germination and Viability of Soybean (Glycine max) and Niger (Guizotia abyssinica) Seeds
}

\author{
Jaya Singh $^{1,2^{*}}$, Seema Paroha ${ }^{2}$ and Ravi Prakash Mishra ${ }^{1}$ \\ ${ }^{1}$ Department of P.G. Studies and Research in Biological Sciences, Rani Durgavati University, \\ Jabalpur-482001, India \\ ${ }^{2}$ Biochemistry Laboratory, Project Co-ordination Unit, All India Coordination Project (Sesame \\ and Niger), Jawaharlal Nehru Krishi Vishwavidyalaya, Jabalpur-482004 India \\ *Corresponding author
}

\section{A B S T R A C T}

Keywords

Soybean, Glycine max, Niger, Guizotia abyssinica, seed germination, storage conditions.

\begin{tabular}{l}
\hline Article Info \\
\hline Accepted: \\
15 June 2016 \\
Available Online: \\
10 July 2016
\end{tabular}

Effect of storage period on seed vigour and germination of soybean and niger, two oil seeds from Central India, were studied. The seeds were stored for a period of 0 7 years in polythene bags under ambient conditions. the study group were control (0 year), short term storage periods (1-3 years) and mid term storage period (4-6 year). Twenty seeds in three replicates were used from each lot for the study. The soybean seeds showed loss of moisture after storage period of two years or more, while niger seeds did not show significant loss of moisture content upto seven years. Soybean seeds showed significant increase in electrical conductivity ( 172.22 $\pm 4.1 \mu \mathrm{S} \mathrm{cm}^{-1} \mathrm{~g}^{-1}$ for 0 year to $470.34 \pm 4.8 \mu \mathrm{S} \mathrm{cm}^{-1} \mathrm{~g}^{-1}$ for 6 years) showing seed deterioration as compared to niger seeds $\left(1.56 \pm 0.07 \mu \mathrm{S} \mathrm{cm}^{-1} \mathrm{~g}^{-1}\right.$ for 0 day to 6.44 $\pm 1.1 \mu \mathrm{S} \mathrm{cm}^{-1} \mathrm{~g}^{-1}$ for 6 years). The soybean seeds stored for mid term storage showed $0-15 \%$ germination while for short term stored seeds, the germination percentage was $40-70 \%$. The niger seeds showed $40-60 \%$ germination for mid term stored seeds and upto $100 \%$ germination for short term stored seeds. The tetrazolium test showed higher numbers of viable seeds in niger as compared to soybean. The study indicates that niger seeds have better storability than soybean seeds under ambient conditions.

\section{Introduction}

Soybean (Glycine max, family fabaceae) is a species of legume native to East and South East Asia, widely grown for its edible bean which has numerous uses. The plant is classed as an oilseed rather than a pulse by the UN Food and Agriculture Organization (FAO). The soybean is preeminent for its high $(38-45 \%)$ protein content as well as its high (approximately 20\%) oil content.
Soybean is the one of the most valuable crop in central part of India. The bulk of the soybean crop is grown for oil production. A smaller percentage of soybeans are used directly for human consumption.

Soybeans occur in various sizes, and in many hull or seed coat colors. The hull of the mature bean is hard, water-resistant, and protects the cotyledon and hypocotyl from 
damage. The scar, visible on the seed coat, is called the hilum and at one end of the hilum is the micropyle, or small opening in the seed coat which can allow the absorption of water for sprouting. Remarkably, seeds contain very high levels of protein and can undergo desiccation, yet survive and revive after water absorption. Niger seed resembles sunflower seeds in shape, but is smaller in size and black. It bears a fairly thick, adherent seed coat and can be stored for up to a year without deterioration.

Niger (Guizotia abyssinica) belongs to the family Asteraceae, is an erect, stout, branched annual herb, grown for its edible oil and seed. Its cultivation originated in the Ethiopian highlands, and has spread to other parts of the world including India. Niger seed yields about $30-35 \%$ of its weight in oil which is polyunsaturated oil with a nutty taste and sweet odor. It's fatty acid composition is similar to sunflower oil and has high content of linoleic acid.

Seed are usually stored for varying lengths of time after harvest. Viability at the end of any storage period is the result of the initial viability at harvest, as determined by factors of production, methods of handling and rate at which deterioration takes place. This rate of physiological change varies with the kind of seed and the environmental condition of storage primarily temperature and humidity (Hartmann and Kesler, 1993). During storage, seed quality is affected by several factors like environmental conditions during seed production, pests, diseases, seed oil content, seed moisture content, mechanical damages of seed during processing, packaging materials, pesticides, air temperature and relative air humidity in storage (TeKrony and Egli, 1991; Reuzeau and Cavalie, 1995; Al-Yahya, 2001; Guberac et al., 2003).

Longevity of seed in storage is influenced by the seed quality as well as storage conditions. Storage of seeds with high initial quality will maximize accession longevity. Irrespective of initial seed quality, unfavourable storage conditions, particularly air temperature and air relative humidity, contribute to accelerating seed deterioration during storage. Hence, it is difficult to assess the effective storage period because the storability of the seed is a function of initial seed quality and the storage conditions, and may vary among different seed types (Anfinrud, 1997; Fabrizius et al., 1999; Heatherly and Elmore, 2004). Monitoring viability during storage facilitates timely identification of accessions that require regeneration to ensure continued availability of conserved germplasm.

The present study is an attempt to identify the effect of storage conditions on germination of soybean and niger seeds over a period of seven years (2008-2014) under same environmental conditions, in order to compare the storage time and conditions on two types of oilseeds.

\section{Materials and Methods}

The seeds of soybean and niger were harvested during from 2008 to 2015. The soybean seeds were obtained from Soybean research Institute, Indore. The niger seeds were harvested each year from the crops cultivated at the premises of Jawaharlal Nehru Krishi Vishwavidyalaya, Jabalpur India and stored in sealed polythene bags under normal environmental conditions in different batches at the Department of Seed Technology, Jawaharlal Nehru Krishi Vishwavidyalaya, Jabalpur, India. Storage temperature and relative humidity were monitored each day throughout the experiment but were not controlled. One sample lot from each storage year was used for the experiments. All seed samples were subjected to determine seed moisture content, electrolyte leakage, germination and seed viability. 


\section{Determination of Seed moisture content}

The empty bottle was weighed, then put it in oven at $105^{\circ} \mathrm{C}$ for $3 \mathrm{~h}$. After that, the bottle was weighed and placed in an oven for $1 \mathrm{~h}$, until it achieves the constant weight. Five grams of seeds were placed in each bottle and weighed, dried at $105^{\circ} \mathrm{C}$ for $2 \mathrm{~h}$ until it reaches the constant weight. The moisture content was calculated for six replicates of both seeds from each storage year. The seed moisture content in percentage was calculated as per the formula given by Sutopo (1988)-

Moisture \% =

Weight of the bottle with seed before drying -

weight of the bottle with seed after drying

Weight of bottle with seed - weight of bottle

\section{Determination of electrolyte leakage}

Electrolyte leakage was determined by the method of Tatipata (2009). Electrolyte leakage was measured as increase in electrical conductivity by adding $100 \mathrm{ml}$ deionized water to each of 50 weighed seeds. The seeds were incubated for $24 \mathrm{~h}$ at room temperature. The electrical conductivity of the soak water was measured by using conductivity meter (EI, India). Electrolyte leakage of the three replicate of each storage year was presented as $\mu \mathrm{S} \mathrm{cm}^{-1}$ $\mathrm{g}^{-1}$.

\section{Assessment of seed germination}

All samples were tested for standard germination (embryonic axis longer than 1 $\mathrm{cm})$. Seeds (20 number) removed yearwise from the stored lot were placed in the filter paper, wetted with distilled water in three replicates. The number of seeds germinated for 5 days was recorded daily.

\section{Assessment of seed viability}

The tetrazolium test was performed according to the procedure devised by International Seed Testing Association (1999). One hundred seeds from each seed lot of soybean or niger were used for this test in five replications of 20 seeds each. The seeds were soaked in distilled water for $24 \mathrm{~h}$ before staining to allow complete hydration of all the tissues. The seeds were then bisected longitudinally to expose the embryo and stained with $1 \%$ solution (w/v) of triphenyl tetrazolium chloride (TTC) made by dissolving the 2,3,5 TTC in double distilled water. The seeds were then placed in $1 \%$ TTC solution in petridishes on double sheets of Watman No.1 filter paper moistened with distilled water, which were then covered with aluminum foil and incubated at $30 \pm 1{ }^{\circ} \mathrm{C}$ temperature in dark for $36 \mathrm{~h}$.

The tissues of the living cells of the seed took up the stain in different patterns during this period. After staining, the solution was drained off and seeds were rinsed with tap water. Viability of each seed was interpreted according to the topographical staining pattern of the embryo and the intensity of the colouration with the help of magnifying glass and the pattern of each individual seed was recorded under three staining categories, completely colored embryos (viable), partially coloured (potentially viable) and completely colorless embryos (not viable).

\section{Statistical analysis}

The triplicate data of each factor analyses were analysed for significant differences using one way ANOVA. The statistical analysis was performed using Sigma Graphpad Prism® Software Version 6.0. 


\section{Results and Discussion}

The results for the moisture content of soybean showed that soybean seeds lost their moisture rapidly after two years of storing period. The moisture contents for the seeds from 2008 to 2013 were significantly different from that of seeds of 2015 (one way ANOVA, $\mathrm{p}<0.05$ ). On the other hand, niger seeds maintained the moisture percent during storage and the moisture percents for the seeds of 2008 to 2014 were not significantly different from seeds of 2015 (one way ANOVA, $\mathrm{p}<0.05$ ) (Table 1).

The electrolytes are leaked from the seeds when the seeds are allowed to soak in water. The higher electrolyte leakage from the seeds is a measure of seed deterioration, and can be measured as elevated electrical conductivity in soak water. When the electrical conductivity was measured to identify the level of electrolyte leakage as a function of seed damage, the soybean seeds of short term storage did not show significant elevated electrical conductivities (EC), although the seeds from 2012 did differ from the control seeds (one way ANOVA, $\mathrm{p}<0.05)$. The soybean seeds stored for mid-term showed considerable and significant increase in EC indicating loss of vigor. Niger seeds followed the trend where the seeds from 2013 and older showed significant differences in electrical conditivities as compared to control seeds (one way ANOVA, $\mathrm{p}<0.05$ ). However, the electrolyte leakage was relatively stable during the midterm storage period (Table 2).

The germination studies of the seeds of different storage periods for the soybean showed that no seed started germinating after $24 \mathrm{~h}$. The seeds of year 2015 and 2014 started germination from second day. After $5^{\text {th }}$ day, the seeds of the years 2009 and 2010 failed to show any germination. The seeds of the year 2011 showed only $15 \%$ germination after five days. The seeds of the year 2012, 2013 and 2014 showed $40 \%$, 55\% and 70\% germination respectively. Only seeds of year 2015 showed $100 \%$ germination after five days.

The seeds of niger started germinating only after $48 \mathrm{~h}$. Although, the seeds started germinating late, after fifth day, the short terms stored seeds of the year 2009, 2010 and 2011 showed $0 \%, 40 \%$ and 60\% germination respectively. Among the mid termed stored seeds of year 2012, 2013 and 2014 , the germination rates were $70 \%, 95 \%$ and $100 \%$ respectively. A day-wise comparative seed germination is presented in Fig 1.

The seed viability studies were performed using tetrazolium (TZ) test. Upon staining with TZ, only 30\% seeds from year 2015 harvest showed completely couloured embryos, while $65 \%$ seeds showed partially coloured enbroys. The older the soybean seeds, higher the number of partially colored seeds was found. In case of niger seeds, the percentage of completely colored seeds was higher and the seeds harvested from year 2011 and later showed more than 50\% of completely colored seeds (Table 3 ).

Changes occurring in seed during storage are valuable study tools to study seed quality and seed longevity. The seeds containing high oil percentage show considerable changes in the chemical composition under specific environmental and aging conditions. The soybean and niger are the two important oilseeds of Madhya Pradesh (India) and hence the studies on the seed germination under different storage conditions is a prerequisite to identify the best storage conditions for the seeds to minimize the deterioration rates. The results clearly indicated that the soybean seeds lost moisture at a higher rate, and this may be the prime reason why the older seeds of soybean 
failed to germinate. The results were supported by the electrolyte leakage and tetrazolium viability tests. On the other hand, niger seeds were able to retain the seed moisture, and hence the older seeds were more viable as compared to soybean seeds. Earlier, Gladys et al. (2012) have shown that the soybean varieties can maintain high viability for up to 12 months under all tested storage conditions, and untreated seeds' viability declined drastically after one year. Vieira et al. (2001) depicted that the decline in seed viability is intricately linked to the moisture content of the seed, which depends on the relative humidity of the storage environment.

The germination time for niger seeds was higher as compared to the soybean seeds during the present study. The niger seeds having short term storage, started germination after three days. The results are in line with the findings of Dwivedi (2014) who showed the germination time from 2 to 5 days for the niger seeds under different treatments. Further, more than 50\% germination and seed viability was found with the niger seeds that were older than 6 years as compared to compared. The results show that the niger seeds are tougher as compared to soybean seeds. The reason may be the thick adherent seed coat on the niger seeds, which prevents the loss of moisture during storage. In another study by Balešević-Tubić et al. (2010), a comparison of storage conditions on seed viability of soybean and sunflower seeds showed that soybean seeds are more sensitive to damage and reduced germination during storage. Further, the authors discussed that in addition to the cultivar, storage conditions, and duration were significant factors affecting the germination rates of soybean.

Table.1 Moisture percentage of stored seeds of soybean and niger. Data are presented as mean \pm standard deviation of six replicates. Different letters show the significant differences from control (seeds of year 2015) for each seed type.

\begin{tabular}{c|c|c|c|c}
\hline & & & \multicolumn{2}{|c}{ Moisture \% (mean \pm SD, n=6) } \\
\cline { 3 - 5 } S.No. & Storage group & Year of harvesting & Soybean & Niger \\
\hline 1. & Control (0 year) & 2015 & $6.83 \pm 0.01^{\mathrm{a}}$ & $4.55 \pm 0.06^{\mathrm{a}}$ \\
\hline 2. & Short Term & 2014 & $6.78 \pm 0.02^{\mathrm{a}}$ & $3.62 \pm 0.06^{\mathrm{a}}$ \\
3. & $(1-3$ years) & 2013 & $4.74 \pm 0.03^{\mathrm{b}}$ & $3.15 \pm 0.03^{\mathrm{b}}$ \\
4. & & 2012 & $4.51 \pm 0.02^{\mathrm{b}}$ & $4.05 \pm 0.05^{\mathrm{a}}$ \\
\hline 5. & \multirow{2}{*}{ Mid Term } & 2011 & $4.53 \pm 0.02^{\mathrm{b}}$ & $4.17 \pm 0.04^{\mathrm{a}}$ \\
6. & (4-6 years) & 2010 & $2.99 \pm 0.32^{\mathrm{c}}$ & $3.28 \pm 0.06^{\mathrm{b}}$ \\
7. & & 2009 & $2.06 \pm 0.10^{\mathrm{c}}$ & $4.48 \pm 0.07^{\mathrm{a}}$ \\
\hline
\end{tabular}

*Different superscript letters denote significant differences between groups 
Table.2 Electrolyte conductivity of the soak water of soybean and niger seeds during the different storage periods. Data are presented as mean $\pm \mathrm{SD}(\mathrm{n}=3)$.

\begin{tabular}{|c|c|c|c|c|}
\hline \multirow{2}{*}{ S. No. } & \multirow{2}{*}{ Storage group } & \multirow{2}{*}{$\begin{array}{c}\text { Harvesting } \\
\text { year }\end{array}$} & \multicolumn{2}{|c|}{ Electrical conductivity $\left(\mu S \mathrm{~cm}^{-1} \mathrm{~g}^{-1}\right)$} \\
\hline & & & Soybean & Niger \\
\hline 1. & $\begin{array}{l}\text { Control } \\
(0 \text { year })\end{array}$ & 2015 & $172.22 \pm 4.1^{\mathrm{a}}$ & $1.56 \pm 0.07^{\mathrm{a}}$ \\
\hline $\begin{array}{l}2 . \\
3 . \\
4 .\end{array}$ & $\begin{array}{l}\text { Short Term } \\
\text { (1-3 years) }\end{array}$ & $\begin{array}{l}2014 \\
2013 \\
2012 \\
\end{array}$ & $\begin{array}{l}191.11 \pm 6.1^{\mathrm{a}} \\
200.02 \pm 6.9^{\mathrm{a}} \\
251.18 \pm 3.2^{\mathrm{b}}\end{array}$ & $\begin{array}{c}2.72 \pm 0.09^{a} \\
5.26 \pm 0.8^{b} \\
5.51 \pm 1.1^{b}\end{array}$ \\
\hline $\begin{array}{l}5 . \\
6 . \\
7 .\end{array}$ & $\begin{array}{l}\text { Mid Term } \\
\text { (4-6 years) }\end{array}$ & $\begin{array}{l}2011 \\
2010 \\
2009\end{array}$ & $\begin{array}{l}336.63 \pm 5.9^{c} \\
434.04 \pm 4.2^{c} \\
470.34 \pm 4.8^{c}\end{array}$ & $\begin{array}{l}6.31 \pm 1.2^{b} \\
6.43 \pm 0.9^{b} \\
6.44 \pm 1.1^{b}\end{array}$ \\
\hline
\end{tabular}

*Different superscript letters denote significant differences between groups

Table.3 Viability soybean and niger seeds stored for different time periods under same conditions.

\begin{tabular}{c|c|cc|cc|cc}
\hline Storage group & Year & \multicolumn{2}{|c|}{$\begin{array}{c}\text { No. of completely } \\
\text { coloured seeds }\end{array}$} & \multicolumn{2}{|c|}{$\begin{array}{c}\text { No. of partially } \\
\text { coloured seeds }\end{array}$} & \multicolumn{2}{|c}{$\begin{array}{c}\text { No. of colourless } \\
\text { seeds }\end{array}$} \\
\cline { 3 - 8 } & & Soybean & Niger & Soybean & Niger & Soybean & Niger \\
\hline Control & 2015 & 6 & 20 & 13 & 0 & 1 & 0 \\
\hline (0 year) & & & & & & & 0 \\
Short Term & 2014 & 3 & 20 & 17 & 0 & 0 & 0 \\
(1-3 years) & 2013 & 0 & 11 & 17 & 9 & 3 & 3 \\
\hline \multirow{2}{*}{ Mid term } & 2012 & 1 & 12 & 18 & 5 & 1 & 0 \\
(4-6 years) & 2010 & 1 & 11 & 20 & 9 & 0 & 0 \\
\hline
\end{tabular}


Fig.1 Germination of soybean and niger seeds stored for different periods.

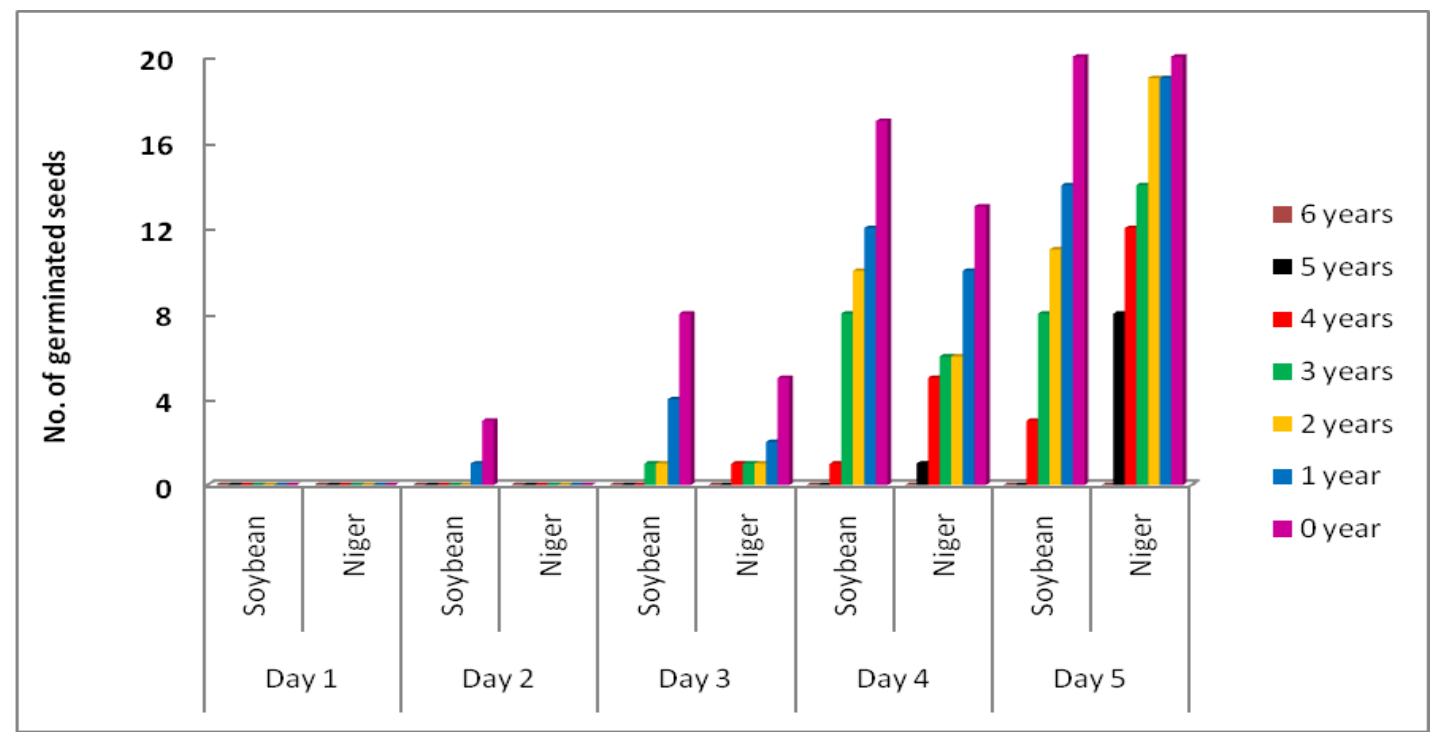

It has been established fact now that the longevity of the seeds under storage conditions exert significant influence on germination of the seeds (Nkang and Umoh, 1997). Further, a declining trend was observed in total oil content and seed germination rates during the storage of oilseed species (Sharma, 1977). The degree as well as speed of decline in seed vigor depend strongly upon plant species, storage conditions as well as quality of the initial seeds (Balešević-Tubić et al., 2005). One more reason why soybean seeds showed decreased seed quality may be the fact that the radicle of the soybean embryonic axis is susceptible to deterioration because of its proximity to the funicular end. Because of this, the seed is directly in contact with both water and oxygen, which enter through the hilum causing lipid peroxidation (McDonald, 1999) compromising the seed vigor and quality.

The present study concludes that the seeds of soybean cannot be stored for more than a year in polythene bags, while the niger seeds can be stored upto five years without much loss of seed germination capabilities.

\section{Acknowledgement}

The authors are thankful to the Head, Department of P.G. Studies and Research in Biological Sciences, Jabalpur and Head, Department of Seed Science, Jawaharlal Nehru Krishi Vishwavidyalaya, Jabalpur for laboratory facilities.

\section{References}

Al-Yahya, S.A. 2001. Effect of storage conditions on germination in wheat. $J$. Agronom. Crop Sci., 186(4): 273-279.

Anfinrud, M.N. 1997. Planting hybrid seed production and seed quality evaluation. Sunflower Tech. Prod., (sunflowertechno), 697-708.

Balešević-Tubić, S., Malenćić, D., Tatić, M. and Miladinović, J. 2005. Influence of aging process on biochemical changes in sunflower seed. Helia, 28(42): 107114.

Balešević-Tubić, S., Tatić, M., Đorđević, V., Nikolić, Z., and Đukić, V. 2010. Seed viability of oil crops depending on storage conditions. Helia, 33(52): 153160.

Dwivedi, S. 2014. Germination behaviour of 
Guizotia abyssinica (L.F.) Cass. (Niger) as influenced by some special treatments. Inter. J. Sudan Res., 4(1): 55-65.

Fabrizius, E., TeKrony, D., Egli, D. B., and Rucker, M. 1999. Evaluation of a viability model for predicting soybean seed germination during warehouse storage. Crop Sci., 39(1): 194-201.

Gladys, C.Y.M. 2012. Effects of maturity group, seed composition and storage conditions on the quality and storability of soybean (Glycine max L. Merrill) seed. Graduate Thesis and Dissertation, Lowa State University, USA.

Guberac, V., Maric, S., Lalic, A., Drezner, G., and Zdunic, Z. 2003. Hermetically sealed storage of cereal seeds and its influence on vigour and germination. J. Agron. Crop Sci., 189(1): 54-56.

Hartmann, H.T., and Kesler, D.E. 1993. Principle and practices of plant propagation and storage. Fourth ed. New Jersey, Prentice Hall press, p. 90.

Heatherly, L.G., and Elmore, R.W. 2004. Managing inputs for peak production. In: Soybeans: Improvement, Production and Uses. Eds- Boerma H.R., Specht, J.E. 3rd Edition, Agronomy N-16, ASA, CSSA, SSSA, Madison, Wisconsin, USA, pp. 451536.

International Seed Testing Association (ISTA). 1999. International rules for seed testing. International Seed Testing Association, Switzerland.

McDonald, M.B. 1999. Seed deterioration : Physiology, repair and aasessment.
Seed Sci. Technol., 27: 177-237.

Nkang, A. and Umoh, E.O. 1997. Six month storability of five soybean cultivars as influenced by stage of harvest, storage temperature and relative humidity. Seed Sci. Technol., 25: 93-99.

Owolade, O.F., Olasoji, J.O., Afolabi, C.G. 2011. Effect of storage temperature and packaging materials on seed germination and seed-borne fungi of sorghum (Sorghum bicolor (L.) Moench.) In South West Nigeria. Afri. J. Plant Sci., 5(15): 873-877.

Reuzeau, C., Cavalie, G. 1995. Activities of free radical processing enzymes in dry sunflower seeds. New phytol., 130(1): 59-66.

Sharma, K.D. 1977. Biochemical changes in stored oil seeds. Ind. J. Agri. Res., 11(3): 137-141.

Sutopo, L. 1988. Seed Technology. Agriculture Faculty of Brawijaya University. Jakarta: CV. Rajawali.

Tatipata, A. 2009. Effect of seed moisture content, packaging and storage period on mitochondria inner membrane of soybean seed. J. Agri. Tech., 5(1): 5164.

TeKrony, D.M., Egli, D.B., 1991. Relationship of seed vigor to crop yield: a review. Crop Sci., 31(3): 816822.

Vieira, R.D., TeKrony, D.M., Egli, D.B. and Rucker, M. 2001. Electrical conductivity of soybean seeds after storage in several environments. Seed Sci. Technol., 29: 599-608.

\section{How to cite this article:}

Jaya Singh, Seema Paroha and Ravi Prakash Mishra. 2016. Effect of Storage on Germination and Viability of Soybean (Glycine max) and Niger (Guizotia abyssinica) Seeds. Int.J.Curr.Microbiol.App.Sci. 5(7): 484-491. doi: http://dx.doi.org/10.20546/ijcmas.2016.507.053 